\title{
A Hypercaloric Pellet-Diet Cycle Induces Obesity and Co-Morbidities in Wistar Rats
}

\section{original}

\author{
ANDRÉ F. NASCIMENTO \\ MárIo M. SUGIZAKI \\ ANDRÉ S. LEOPOLDO \\ ANA P. LIMA-LEOPOLDO \\ RenATA A. M. LUVIzOTIO \\ Célia R. Nogueira \\ ANTONIO C. CICOgNa
}

Departamento de Clínica

Médica e Laboratório

Experimental da Clínica Médica da Faculdade de Medicina de

Botucatu, Universidade Estadual

Paulista (Unesp).

Recebido em 4/3/2008

Aceito em 4/7/2008

\section{ABSTRACT}

The present study was carried to develop and analyze the consequences of hypercaloric pellet-diet cycle that promotes obesity in rats. Male Wistar rats were randomly distributed into two groups that received either normal diet (ND; $\mathrm{n}=32 ; 3,5 \mathrm{Kcal} / \mathrm{g}$ ) or a hypercaloric diet (HD; $\mathrm{n}=32 ; 4,6 \mathrm{Kcal} / \mathrm{g}$ ). The ND group received commercial Labina rat feeding while the $\mathrm{HD}$ animals received a cycle of five hypercaloric diets over a 14-week period. The effects of the diets were analyzed in terms of body weight, body composition, hormone-metabolite levels, systolic arterial pressure and glucose tolerance at the $5 \%$ significance level. The hypercaloric pellet diet cycle promoted an increase in body weight and fat, systolic arterial pressure and a high serum level of glucose, triacylglycerol, insulin and leptin. The HD group also presented an impaired glucose tolerance. In conclusion, the results of this study show that the hypercaloric pellet-diet cycle promoted obesity in Wistar rats and displayed several characteristics that are commonly associated with human obesity, such as high arterial pressure, insulin resistance, hyperglycaemia, hyperinsulinaemia, hyperleptinaemia and dyslipidaemia. (Arq Bras Endocrinol Metab 2008; 52/6:968-974)

Keywords: Diet induced-obesity; Hypercaloric diet; Metabolic syndrome; Rats

\section{RESUMO}

Ciclo de Dietas Hipercalóricas Induz Obesidade e Comorbidades em Ratos Wistar.

O objetivo do estudo foi desenvolver um ciclo de dietas hipercalóricas para promover obesidade em ratos. Ratos Wistar foram distribuídos em dois grupos: dieta normal (ND $=32 ; 3,5 \mathrm{kcal} / \mathrm{g}$ ) e dietas hipercalóricas $(\mathrm{HD} ; \mathrm{n}=32 ; 4,6$ $\mathrm{kcal} / \mathrm{g}$ ). O grupo ND recebeu ração comercial e os animais HD um ciclo de diferentes dietas hipercalóricas, por 14 semanas. As variáveis analisadas foram peso corporal, parâmetros metabólicos e hormonais, pressão arterial sistólica e teste oral de tolerância à glicose. $O$ nível de significância foi de $5 \%$. O ciclo de dietas hipercalóricas promoveu aumento de peso e gordura corporal, pressão arterial sistólica e níveis séricos de glicose, triacilglicerol, insulina e leptina no grupo HD. Além disso, o grupo HD apresentou tolerância à glicose diminuída. Em conclusão, os resultados deste estudo mostram que o ciclo de dietas hipercalóricas promove obesidade e exibe várias características comumente associadas com a obesidade humana, como aumento da pressão arterial, resistência à insulina, hiperglicemia, hiperinsulinemia, hiperleptinemia e dislipidemia. (Arq Bras Endocrinol Metab 2008; 52/6:968-974)

Palavras-chave: Obesidade induzida por dieta; Dieta hipercalórica; Síndrome metabólica; Ratos 


\section{INTRODUCTION}

$\mathrm{O}$ BESITY IS A COMPLEX multifactor disease characterized by an excessive accumulation of adipose tissue that may impair health. It is found in both developed and developing countries, affects all ages and social classes and it is one of the major risk factors in chronic and incapacitating diseases (1).

Effective studies on the consequences of obesity in humans have ethical limitations. For this reason, genetic and dietetic experimental models have been used to study obesity. Even though genetic mutations cause obesity in animals, the occurrence is rare $(2,3)$. The current World obesity epidemic is a consequence of the high availability and consumption of highly energetic and palliative diets along with a reduction in energy use $(4,5)$. Thus, diet-induced obesity models may be more appropriate to study the pathology of obesity. To this end studies have been developed to obtain obese animals induced by a high fat $(6,7)$ and high carbohydrate intake $(8,9)$ and by cafeteria diets $(10,11)$. In fact, it has been suggested that rats become more obese as a result of consumption of cafeteria diets rather than high-fat diets, indicating perhaps a greater hyperphagia arising from the food variety (12). However, a cafeteria diet presents some limitations, such as the difficulty in determining the consumption of dietary components and the fact that food is offered in natura and may be in deteriorated state. Therefore, the aim of this study was to develop a more controlled diet consisting of a cycle of hypercaloric pellet-dietary formulations with a different palatability to induce experimental obesity in rats. Obesity is considered to be associated with numerous co-morbidities such as a systemic resistance to insulin, hyperglycaemia, dyslipidaemia, hyperleptinaemia, hyperinsulinaemia and systemic arterial hypertension $(6,9,10,13,14)$ and these parameters were therefore investigated.

\section{METHODS}

\section{Animals and experimental model}

This study was performed on thirty-day-old male Wistar rats supplied by São Paulo State University Animal Centre Universidade Estadual Paulista (UNESP), Botucatu, SP. Rats were randomly distributed into two groups which were fed on either a normal diet $(N D ; n=31)$ or a hypercaloric diet (HD; $\mathrm{n}=31)$. ND animals were given commercial Labina rat feeding (Purina ${ }^{\circledR}$, Paulínia, SP, Brazil) and HD animals were submitted to cycles of five hypercaloric diets (HD1, HD2, HD3, HD4, and HD5) offered for seven days. Rats were maintained on this dietary regimen for 14 weeks and then sacrificed. The hypercaloric diet was standardized in our laboratory. The groups received water ad libitum. Food consumption was controlled every day and water was controlled on Mondays, Wednesdays, and Fridays. Body weight was measured weekly. The final body weight to length ratio was also calculated. Length was measured between the nose and the anus of rats, not counting the tail. The feeding efficiency (FE) was calculated to analyze an animal's capacity to convert consumed food energy into body weight. This calculation used total energy ingested by the animals in each cage (Kcal) divided by the average weekly weight gain, multiplied by 100 (15). Ingested energy was calculated by multiplying ingested food quantity by the caloric value of each diet. Caudal arterial systolic pressure $(\mathrm{ND}, \mathrm{n}=23 ; \mathrm{HD}, \mathrm{n}=15)$ was measured at the end of the experiment. Rats were collectively housed in four animals per box, in a temperature controlled $\left(24 \pm 2{ }^{\circ} \mathrm{C}\right)$ environment on a $12-12 \mathrm{~h}$ light-dark cycle. The study protocol was approved by Botucatu School of Medicine Research Ethics Committee - UNESP and followed the Guide for Care and Use of Experimental Animals.

\section{Hypercaloric diets components}

The experimental diets followed specifications from $\mathrm{Nu}$ trient Requirements of the Laboratory Rat as recommended by the National Academy of Sciences. Hypercaloric diets $1,2,4$, \& 5 were designed in our laboratory and contained powdered commercial Labina rat chow (Purina ${ }^{\circledR}$, Paulínia, SP, Brazil), industrialized feed, protein supplement, vitamins and minerals. The ingredients were first ground and then mixed with vitamins and minerals. The mixture was then made into pellets, dried in a ventilated drying oven at $55 \pm 5^{\circ} \mathrm{C}$ and stored at $-20^{\circ} \mathrm{C}$. Diet $\mathrm{H} 3$ was commercial Labina with $300 \mathrm{~g} / \mathrm{L}$ sugar added to drinking water. The ingredients $(\mathrm{g} / \mathrm{kg})$ used to prepare the hypercaloric diets were: HDl: ground Labina, 355; roasted peanuts, 176; casein, 123; corn oil, 82; chocolate, 88; corn biscuits, 176; and, vitamins and minerals; HD2: ground Labina, 439; roasted peanuts, 218; casein, 129; corn oil, 61 ; French fried potatoes, 153; and vitamins and minerals; HD4: ground Labina, 371; roasted peanuts, 185; casein, 99; corn oil, 68; instant noodles, 185; grated cheese, 92; and vitamins and minerals; and HD5: ground Labina, 359; roasted peanuts, 179; casein 105; corn oil, 80 ; condensed milk, 161; wafer biscuit, 116; and vitamins and minerals. 


\section{Dietary nutritional composition evaluation}

Dietary nutritional composition was analyzed by the Animal Nutrition and Improvement Laboratory, School of Agronomy Sciences, UNESP. The amount of protein, fat, fibre and dry material were according to Weende's Method. The following equipment was used: Nitrogen Destilator Tecnal - 036/1, Fat Extractor Adamo $^{\circledR}$ Goldfish, Fibre Determinator Tecnal - TE149 and Sterilization and Dry Oven OdontoBras.

\section{Oral glucose tolerance test}

Rats (ND: $n=17 ; \mathrm{DH}: \mathrm{n}=15$ ) were fasted overnight and blood was sampled for analysis of glucose at 0 (before), $30,60,120,180$ and $240 \mathrm{~min}$ after administration of glucose load $(3.0 \mathrm{~g} / \mathrm{kg}$ by gavage $)$ using a handheld glucometer (Prestige Smart System ${ }^{\circledR}$ ) (16). The tolerance glucose between groups was determined according to the area under a curve of glucose ( 0 to 240 minutes).

\section{Body composition}

Body water, fat and protein content were also determined. The percentage of water was calculated as the difference between pre- and post- drying body weight according to $\mathrm{PPr}-\mathrm{PP} / \mathrm{PPr} \times 100 \%$, where $\mathrm{PPr}=$ predrying weight, and $\mathrm{PP}=$ post-drying weight. Bodies were dried at $100 \pm 5^{\circ} \mathrm{C}$ for $72 \mathrm{~h}$ in a ventilated Fanem ${ }^{\circledR}$ oven. After drying, the body was wrapped in paper filter and fat was extracted using a Soxhlet extractor (Corning Incorporated, USA). The percentage of body fat was calculated as PP-PSSG/PPr x 100\%, where PP $=$ post-drying weight, $\mathrm{PSSG}=$ dry weight after fat extraction, and PPr = pre-drying weight. After drying and fat extraction, the body was homogenized and nitrogen quantified by the micro-Kjeldahl method (17). Protein was determined as \% nitrogen x PSSG x 6.25/100, where PSSG $=$ dry weight after fat extraction.

\section{Hormone and metabolite determination}

At the end of the treatments all animals underwent a 12 to $15 \mathrm{~h}$ fast, were then anaesthetized with sodium pentobarbital $(40.0 \mathrm{mg} / \mathrm{kg}$, i.p.) and were sacrificed by decapitation. Serum was separated by centrifugation at $3000 \mathrm{rpm}$ for 10 minutes and an enzymatic colorimetric Kit $\left(\mathrm{CELM}^{\circledR}\right.$, São Paulo, Brazil) was used to measure glucose (GL), triacylglycerol (TG), total cholesterol (COL), total proteins (PT), albumin (ALB), and highdensity lipoprotein (HDL). Spectrophotometry was performed with a Micronal ${ }^{\circledR}$, model B 382 spectropho- tometer. Serum insulin and leptin $(\mathrm{ND} ; \mathrm{n}=13 ; \mathrm{HD}=$ 13 ) were measured by the Elisa method using assay kits from Linco Research Inc (Missouri, USA).

\section{Statistical analysis}

The results of general characteristic, body composition and biochemical analyses are expressed as means \pm standard deviation and were submitted to the Student's ttest. Values of body weight evolution are shown as means and upper and lower limits of $95 \%$ confidence intervals for the mean and are compared using two-way analysis of variance for repeated measurements in independent groups. The results were interpreted using the $5 \%$ significance level.

\section{RESULTS}

\section{General characteristics}

The hypercaloric diets $1,2,4$ e 5 were calorically rich (Hypercaloric diets $=4,6 \mathrm{kcal} / \mathrm{g}$ versus normo-caloric diet $=3,5 \mathrm{kcal} / \mathrm{g}$ ), due to a higher fat composition (Table $\mathrm{l}$ ). In the hypercaloric diet 3 , the increase of the caloric value was due to sucrose addition in the water $(1.2 \mathrm{kcal} / \mathrm{ml})$.

Table 1. Composition of normal and hypercaloric diets.

\begin{tabular}{lccccc}
\hline & \multicolumn{5}{c}{ Diets } \\
Components & Normal & HD1 & HD2 & HD4 & HD5 \\
Protein (\%) & 26 & 27 & 28 & 28 & 26 \\
Carbohydrates (\%) & 54 & 43 & 36 & 33 & 43 \\
\hline Fat (\%) & 3 & 20 & 23 & 24 & 20 \\
\hline Others (\%)* & 17 & 10 & 13 & 15 & 11 \\
\hline Calories (Kcal/g) & 3.5 & 4.6 & 4.6 & 4.6 & 4.6 \\
\hline
\end{tabular}

HD1, HD2, HD4, HD5: hypercaloric diets. Diet H3 is not shown above because it consisted of normal Labina diet (Purina, Paulínia, SP) plus sugared water at a concentration of $300 \mathrm{~g} / \mathrm{L}\left(1.2 \mathrm{kcal} / \mathrm{ml}\right.$ water). ${ }^{*}$ Others: vitamins, minerals, cinders and water.

Table 2 and Figure 1 summarize the general characteristics and body weight during the 14-week treatment for the normo-caloric (ND) and hypercaloric diet (HD) groups, respectively. HD rats ingested less food than did $\mathrm{ND}$ rats $(\mathrm{ND}=24.4 \pm 2.2$ and $\mathrm{HD}=17.6 \pm 1.7 \mathrm{~g}$, $\mathrm{p}<0.001$ ), and calorie $(\mathrm{ND}=84.7 \pm 7.6$ and $\mathrm{HD}=$ $88.7 \pm 11.3 \mathrm{Kcal}, \mathrm{p}>0.05)$ and water $(\mathrm{ND}=36.9 \pm 4.4$ and $\mathrm{HD}=37.1 \pm 7.1 \mathrm{ml}, \mathrm{p}>0.05)$ consumption were similar in both groups. Although the quantity of calories were similar in each group, feeding efficiency, or the conversion of calories into body weight, was higher for 
$\mathrm{HD}(\mathrm{ND}=4.95 \pm 0.21$ and $\mathrm{HD}=5.54 \pm 0.16 \mathrm{~g} / \mathrm{kcal}$, $\mathrm{p}<0.001)$. Body weight / length ratio $(\mathrm{ND}=18.6 \pm 1.5$ and $\mathrm{HD}=20.4 \pm 1.4 \mathrm{mmHg}, \mathrm{p}<0.001)$ and systolic arterial pressure $(\mathrm{ND}=116 \pm 8$ and $\mathrm{HD}=127 \pm 10 \mathrm{mmHg}$, $\mathrm{p}<0.001)$ were higher in the HD than in the ND rats. The HD rats presented a higher glucose intolerance than did the ND group $(\mathrm{ND}=16738 \pm 2561$ and $\mathrm{HD}=$ $\left.22767 \pm 3917 \mathrm{~mm}^{2}, \mathrm{p}<0.001\right)$. Although the ND and HD groups started with a similar body weight at week 0 , a significant separation of body weight between the two groups was observed at week 5 that continued throughout the rest of the study.

Table 2. General characteristics of animals.

\begin{tabular}{lcc} 
& \multicolumn{2}{c}{ Animals } \\
Variables & Normal diet & Hypercaloric diet \\
Food ingestion (g) & $24.4 \pm 2.2$ & $17.6 \pm 1.7^{*}$ \\
$\begin{array}{l}\text { Calorie consumption } \\
\text { (kcal) }\end{array}$ & $84.7 \pm 7.6$ & $88.7 \pm 11.3$ \\
Water consumption (ml) & $36.9 \pm 4.4$ & $37.1 \pm 7.1$ \\
$\begin{array}{l}\text { Feeding efficiency } \\
\text { (g/kcal) }\end{array}$ & $4.95 \pm 0.21$ & $5.54 \pm 0.16^{*}$ \\
Final Body Weight (g) & $501 \pm 44$ & $578 \pm 52^{*}$ \\
FBW/Length (g/cm) & $18.6 \pm 1.5$ & $20.4 \pm 1.4^{*}$ \\
SAP (mmHg) & $116 \pm 8$ & $127 \pm 10^{*}$ \\
AUCG (mm²) & $16738 \pm 2561$ & $22767 \pm 3917^{*}$ \\
\hline
\end{tabular}

Values are expressed as means \pm standard deviation. FBW, final body weight; SAP, systolic arterial pressure; AUCG, area under the curve of glucose (0 to 240 minutes). " $p<0.05$ versus normal diet, Student's t-test. ${ }^{1}$ Animal length measured between nose and anus without the tail.

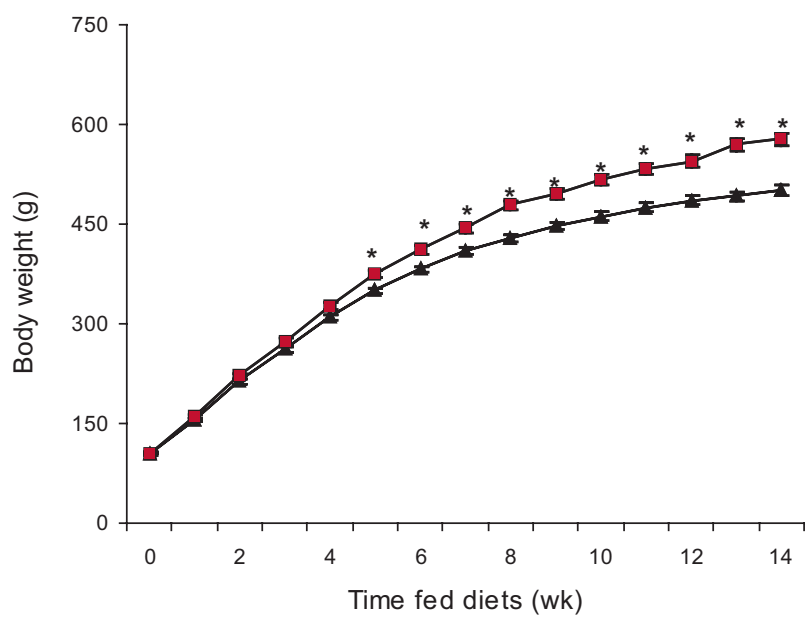

Figure 1. Body weights (mean $\pm \mathrm{SEM}$ ) of a 14-week treatment of normal diet ( $\boldsymbol{\Lambda}$, solid triangles) and hypercaloric diet ( $\boldsymbol{\square}$, solid rectangle) groups. * $\mathrm{p}<0.05$ versus normal diet; ANOVA, Tukey.

\section{Body composition}

Table 3 shows data from the body composition of the ND and $\mathrm{HD}$ groups. Absolute body water $(\mathrm{ND}=225 \pm 22$ and $\mathrm{HD}=249 \pm 26 \mathrm{~g}, \mathrm{p}<0.001)$ and relative body fat $(\mathrm{ND}=$ $18.0 \pm 4.2$ and $\mathrm{HD}=25.5 \pm 4.5 \%, \mathrm{p}<0.001)$ and absolute body fat $(\mathrm{ND}=7 \mathrm{l} \pm 20$ and $\mathrm{HD}=12 \mathrm{l} \pm 31 \mathrm{~g}, \mathrm{p}<0.001)$ were higher in the HD group than in the ND group. The relative body water $(\mathrm{ND}=57.6 \pm 3.3$ and $\mathrm{HD}=53.0 \pm 3.4 \%$, $\mathrm{p}<0.001)$ and relative body protein $(\mathrm{ND}=16.5 \pm 1.3$ and $\mathrm{HD}=14.2 \pm 1.1 \%, \mathrm{p}<0.001)$ were smaller in the HD compared to the ND group.

Table 3. Body composition

\begin{tabular}{lcc} 
& \multicolumn{2}{c}{ Animals } \\
Variables & Normal diet & Hypercaloric diet \\
Body water (g) & $225 \pm 22$ & $249 \pm 26^{*}$ \\
Body water (\%) & $57.6 \pm 3.3$ & $53.0 \pm 3.4^{*}$ \\
Body fat (g) & $71,0 \pm 20,0$ & $121 \pm 31^{*}$ \\
Body fat (\%) & $18.0 \pm 4.20$ & $25.5 \pm 4.45^{*}$ \\
Body protein (g) & $63.9 \pm 4,99$ & $66.6 \pm 7.38$ \\
Body protein (\%) & $16.4 \pm 1.37$ & $14.2 \pm 1.14^{*}$ \\
\hline
\end{tabular}

Values expressed as means \pm standard deviation. $" p<0.05$ versus normal diet using Student's t-test.

\section{Hormone and metabolite determination}

Serum concentrations of glucose $(\mathrm{ND}=99 \pm 19$ and $\mathrm{HD}=114 \pm 33 \mathrm{mg} / \mathrm{dl}, \mathrm{p}<0.05)$ and triacylglycerol (ND $=143 \pm 51$ and $\mathrm{HD}=197 \pm 106 \mathrm{mg} / \mathrm{dl}, \mathrm{p}<0.05)$ were higher in the HD than in the ND rats (Table 4). HDL was lower in the HD animals $(\mathrm{ND}=51 \pm 10$ and $\mathrm{HD}=$ $43 \pm 10 \mathrm{mg} / \mathrm{dl}, \mathrm{p}<0.01)$. The total protein, albumin and total cholesterol levels were similar between the groups. The level of insulin $(\mathrm{ND}=0,45 \pm 0,19$ and $\mathrm{HD}=$ $1,48 \pm 0,67 \mathrm{ng} / \mathrm{dl}, \mathrm{p}<0,05)$ and leptin $(\mathrm{ND}=2,31 \pm 0,53$ and $\mathrm{HD}=4,82 \pm \mathrm{l}, 34 \mathrm{ng} / \mathrm{dl}, \mathrm{p}<0,05)$ were higher in the HD fed animals.

Table 4. Hormone and metabolite determination.

\begin{tabular}{lcc}
\hline & \multicolumn{2}{c}{ Animals } \\
Variables & Normal diet & Hypercaloric diet \\
Total protein $(\mathrm{g} / \mathrm{dl})$ & $6.66 \pm 0.58$ & $6.57 \pm 0.46$ \\
\hline Albumin $(\mathrm{g} / \mathrm{dl})$ & $3.78 \pm 0.53$ & $3.91 \pm 0.51$ \\
Glucose $(\mathrm{mg} / \mathrm{dl})$ & $99,1 \pm 18,7$ & $114 \pm 32,9^{*}$ \\
Triacylglycerol $(\mathrm{mg} / \mathrm{dl})$ & $143 \pm 51,2$ & $197 \pm 106^{*}$ \\
Total cholesterol $(\mathrm{mg} / \mathrm{dl})$ & $66,1 \pm 14,3$ & $68,9 \pm 21,5$ \\
HDL $(\mathrm{mg} / \mathrm{dl})$ & $51,4 \pm 9,68$ & $42,9 \pm 9,59^{*}$ \\
Insulin $(\mathrm{ng} / \mathrm{dl})$ & $0,45 \pm 0,19$ & $1,48 \pm 0,67^{*}$ \\
\hline Leptin $(\mathrm{ng} / \mathrm{dl})$ & $2,31 \pm 0,53$ & $4,82 \pm 1,34^{*}$ \\
\hline & \\
\hline Values expressed as means \pm standard deviation. HDL, high density lipoprotein. \\
"p<0.05 versus normal diet using Student's t-test.
\end{tabular}




\section{DISCUSSION}

The cycle of pelleted hypercaloric diet used in this study was efficient in promoting obesity in rats. This conclusion is based on the finding of increasing body weight and body fat associated with co-morbidities with impaired glucose tolerance, hyperinsulinaemia, hyperleptinaemia, hyperglycaemia, dyslipidaemia and elevated arterial pressure.

The hypercaloric diet used to promote experimental obesity has been presented in either pellet form or as food in natura, the second better known as cafeteria diets (10). These latter types of diet are highly energetic, tasty and contain different shapes and are therefore much closer to the food consumed in general by humans. However, they have some drawbacks, since they are offered in natura they may deteriorate and it is also difficult to quantify how much food animals consume. The cycle pellet-hypercaloric diet model used in this study was based on cafeteria diet since that has been suggested that rats become more obese on this fare (12). Several advantages of our pellet-diet model in relation to the cafeteria diet are the knowledge of food components and caloric consumption and the fact that it is stored in pellets means that is less perishable, thus helping to maintain food integrity. Hypercaloric diets $1,2,4$, and 5 were isocaloric and had $31 \%$ more energy content than the standard diet and are in accordance with studies that have promoted diet-induced obesity $(6,7,9)$. One objective of our cyclic pellet-hypercaloric diet model was to increase food ingestion levels by varying palatability, however, the HD group ingested less food. This result is in at variance with previous studies, since it has been proposed that hyper-lipid diets cause less satiation and consequently result in higher food ingestion levels $(9,18,19)$. The hypophagia observed in the HD group may be due to the high serum leptin level (Table 4). Leptin, a hormone synthesized and secreted by adipose tissue, is mainly involved in the regulation of appetite and energy metabolism. The binding of leptin to the appropriate leptin-receptor triggers intracellular signalling processes in the ventromedial hypothalamus (satiety centre), which, in turn, signals the brain that adequate food has been ingested (20).

Despite a lack of caloric excess consumption the body weight gain was increased in the HD rats. The increase of body weight was a consequence of the body fat storage enhancement, since the increasing caloric density was due to higher fat composition, i.e., seven times the standard diet (Table 1), as confirmed by carcass analysis (Table 3 ). This interpretation is based on previous studies that demonstrate a high fat accumulation when more energy comes from dietary fat than from carbohydrate or protein $(21,22)$. The enhanced body weight gain, induced by the diet in the present work, is in agreement with some studies that used cafeteria $(10,11)$ or hypercaloric diets $(6,7,23)$, but not with all studies $(16,24,25)$. However, the fact that the time to reach increase body weight in our diet is similar to other models $(7,11)$ lends strength to our interpretation.

Obesity has been characterized by numerous comorbidities in addition to elevated weight and body fat, as mentioned above, including systemic insulin resistance, hyperinsulinaemia, hyperleptinaemia, hyperglycaemia, dyslipidaemia and elevated systolic arterial pressure $(6,9,10,13,14)$. The increase in body weight and fat, due to the hypercaloric pellet-diet cycle used in this work, was associated with these co-morbidities. The increase of systolic arterial pressure may be due to a number of factors, including sympathetic autonomic system activation $(23,26)$, higher activity in the renin-angiotensin system $(24,27,28)$, oxidative stress $(26)$ and an increase of free fatty acid (29), insulin (30) and leptin (31), all being observed in obesity. The impaired glucose tolerance associated to hyperglycaemia and hyperinsulinaemia in HD animals indicates that hypercaloric pellets-diet promoted insulin resistance, a state in which higher concentrations of insulin is required to maintain normoglycaemia $(32,33)$. It is well established that increased availability and utilization of free fatty acids play a critical role in the development of insulin resistance. Excess adipose tissue has been shown to release an increased amount of free fatty acids which directly affect insulin signalling, diminishes glucose uptake in muscle, drives exaggerated triglyceride synthesis and induces gluconeogenesis in the liver $(34,35)$. The elevated serum levels of glycaemia and triacylglycerol associated with insulin resistance in this study indicate that an abundance of free fatty acids may be responsible for the co-morbidities observed in the hypercaloric diet model.

In conclusion, the results of this study show that the hypercaloric pellet-diet cycle model promoted obesity in Wistar rats and displayed several characteristics that are commonly associated with human obesity, including high arterial pressure, insulin resistance, hyperglycaemia, hyperinsulinaemia, hyperleptinaemia and dyslipidaemia. This dietary model may therefore be suitable for a systematic investigation of the dietary fat 
role in body weight regulation and other questions directly related to obesity.

Acknowledgments: The authors would like to thank José Carlos Georgete, Mário Baptista Bruno and Sandra Fábio for technical assistance. This manuscript has been proofread and edited by native English speakers with related background in BioMed Proofreading (Cleveland, Ohio, USA). There are no conflicts of interest in this study.

\section{REFERENCES}

1. World Health Organization - WHO [homepage on the Internet]. Obesity and overweight. Geneva; 2006. Available from: http://www.who.int. /mediacentre/factsheets/fs311.

2. Lubrano-Berthelier C, Cavazos M, Dubern B, Shapiro A, Stunff $\mathrm{CL}$, Zhang $\mathrm{S}$, et al. Molecular genetics of human obesity-associated MC4R mutations. Ann N Y Acad Sci. 2003;994:49-57.

3. Carroll J, Voisey J, Daal AV. Mouse models of obesity. Clin Dermatol. 2004;22:345-9.

4. Astrup A, Buemann B, Western P, Toubro S, Raben A. Obesity as an adaptation to a high-fat diet: evidence from a cross-sectional study. Am J Clin Nutr. 1994;59:350-5.

5. Lissner $L$, Heitmann BL. Dietary fat and obesity: evidence from epidemiology. Eur J Clin Nutr. 1995 49:79-90.

6. Woods SC, Seeley RJ, Rushing PA, D'Alessio D, Tso P. A controlled high-fat diet induces an obese syndrome in rats. J Nutr. 2003;133:1081-7.

7. Relling DP, Esberg LB, Fang CX, Johnson WT, Murphy EJ, Carlson EC, et al. High-fat diet-induced juvenile obesity leads to cardiomyocyte dysfunction and upregulation of foxo3a transcription factor independent of lipotoxicity and apoptosis. J Hypertens. 2006;24:549-61.

8. Beltowski J, Wojcicka G, Gorny D, Marciniak A. The effects of dietary-induced obesity on lipid peroxidation, antioxidant enzymes and total plasma antioxidant capacity. J Physiol Pharmacol. 2000;51:883-96.

9. Dourmashkin JT, Chang GO, Gayles EC, Hill JO, Fried SK, Julien C, et al. Different forms of obesity as a function of diet composition. Int J Obes. 2005;9:1-11.

10. Sclafani A, Springer D. Dietary obesity in adults rats: similarities to hypothalamic and human obesity syndromes. Physiol Behav. 1976;17:461-71.

11. Esteve M, Immaculada R, Fernandez-Lopez JA, Remesar X, Alemany $M$. Effects of a cafeteria diet on energy intake and balance in Wistar rats. Physiol Behav. 1994;56:65-71.

12. West DB, York B. Dietary fat, genetic predisposition, and obesity: lessons from animals models. Am J Clin Nutr. 1998;67:505S-12S.

13. Akiyama T, Tachibana I, Shirohara H, Watanabe N, Otsuki M. High-fat hypercaloric diet induces obesity, glucose intolerance and hyperlipidaemia in normal adult male wistar rat. Diab Res Clin Pract. 1996;31:27-35.

14. Jang I, Hwang D, Lee J, Chae K, Kim Y, Kang T. Physiological difference between dietary obesity-susceptible and obesity resistant Sprague Dawley rats in response to moderate high fat diet. Exp Anim. 2003;52:99-107.

15. Surwit RS, Feinglos MN, Rodin J, Sutherland A, Petro $A E$, Opara EC, et al. Differential effects of fat and sucrose on the development of obesity and diabetes in C57BL/6J and $\mathrm{A} / \mathrm{J}$ mice. Metabolism. 1995;44:645-51.

16. Borst SE \& Conover CF. High-fat diet induces increased tissue expression of TNF- $\alpha$. Life Sci. 2005;77:2156-65.

17. Kjeldahl. Official methods of analysis. 12. ed. Washington: Association of Official e Agriculture Chemists. 1970.

18. Green SM, Burley VJ, Blundell JE. Effect of fat- and sucrose containing foods on the size of eating episodes and energy intake in lean males: potential for causing overconsumption. Eur J Clin Nutr. 1994;48:547-55.

19. Blundell JE, Burley VJ, Cotton JR, Lawton CL. Dietary fat and the control of energy intake: evaluating the effects of fat on meal size and postmeal satiety. Am J Clin Nutr. 1993;57:777-8.

20. Trayhurn P, Beattie JH. Physiological role of adipose tissue: with adipose tissue as an endocrine and secretory organ. Proc Nutr Soc. 2001;60:329-39.

21. Lean ME, James WP. Metabolic effects of isoenergetic nutrient exchange over 24-hours in relation to obesity in women. Int $\mathrm{J}$ Obes. 1988;12:15-27.

22. Horton TJ, Drougas H, Brachey A, Reed GW, Peters JC, Hill JO. Fat and carbohydrate overfeeding in humans: different effects on energy storage. Am J Clin Nutr. 1995;62:19-29.

23. Barnes MJ, Lapanowski K, Conley A, Rafols JA, Jen KLC, Dunbar JC. High fat feeding is associated with increased blood pressure, sympathetic nerve activity and hypothalamic mu opioid receptors. Brain Res Bull. 2003;61:511-9.

24. Okere IC, Chandler MP, McElfresh TA, Rennison JH, Sharov V, Sabbah HN, et al. Differential effects of saturated and unsaturated fatty acid diets on cardiomyocyte apoptosis, adipose distribution, and serum leptin. Am J Physiol Heart Circ Physiol. 2006;291:39-44.

25. Pinotti MF, Silva MD, Sugizaki MM, Diniz YS, Sant'Ana LS, Aragon FF, et al. Effect of unsaturated fatty acids on myocardial performance, metabolism and morphology. Braz J Med Biol Res. 2006;39:305-12.

26. Pausova Z. From big fat cells to high blood pressure: a pathway to obesity-associated hypertension. Curr Opin Nephrol Hypertens. 2006;15:173-8.

27. Fitzgerald SM, Henegar JR, Brands MW, Henegar LK, Hall JE. Cardiovascular and renal responses to a high-fat diet in Osborne-Mendel rats. Am J Physiol Regul Integr Comp Physiol. 2001;281:H547-52.

28. Boustany-Kari CM, Gong M, Akers WS, Guo Z, Cassis LA. Enhanced vascular contractility and diminished coronary artery flow in rats made hypertensive from diet-induced obesity. Int J Obes. 2006;14:778-86.

29. Tripathy D, Mohanty P, Dhindsa S, Syed T, Ghanim H, Aljada A, et al. Elevation of free fatty acids induces inflammation and impairs vascular reactivity in healthy subjects. Diabetes. 2003;52:2882-7.

30. Defronzo RA, Cooke CR, Andres R, Faloona GR, Davis PJ. The effects of insulin on renal handling of sodium, potassium, calcium, and phosphate in man. J Clin Invest. 1975;55:845-55.

31. Ren J. Leptin and hyperleptinaemia - from friend to foe for cardiovascular function. J Endocrinol. 2004;181:1-10.

32. Wang CC, Goalstone ML, Draznin B. Molecular mechanisms of insulin resistance that impact cardiovascular biology. Diabetes. 2004;53:2735-40. 
Nascimento et al.

33. Eckel RH, Grundy SM, Zimmet PZ. The metabolic syndrome. Lancet. 2005;365:1415-28.

34. Proietto J. Mechanisms of insulin resistance caused by nutrient toxicity. Hepatol Res. 2005;33(2):87-91.

35. Mlinar B, Marc J, Janez A, Pfeifer M. Molecular mechanisms of insulin resistance and associated diseases. Clinica Chimica Acta. 2007;375:20-35.

\section{Correspondence to:}

Antonio Carlos Cicogna

Departamento de Clínica Médica - FMB-Unesp

Distrito de Rubião Jr., s/n; Botucatu/SP.

E-mail: nascimentoaf@yahoo.com.br 